\title{
Keterkaitan Efisiensi Teknis dan Perilaku Risiko Petani Usahatani Bawang Merah Varietas Manjung
}

\author{
Linkage of Technical Efficiency and Farmer Risk Behaviour of Shallot Manjung \\ Variety Production
}

Siti Rahmania Fajri ${ }^{1}$ dan Elys Fauziyah ${ }^{1 *}$

Diterima 30 November 2016/Disetujui 25 Oktober 2017

\begin{abstract}
Pojanan Village of Pamekasan District is wellknown as central producer for Manjung Variety of shallot. This variety has advantages such as high productivity, drought-resistant, pests and diseases resistant, fragrant aroma, and savory taste. However, there is low productivity problem that doesnot meet maximum potential expectation. Therefore, this study aimed to analyze the level of technical efficiency, farmers risk behavior, and interrelations between both issues. There were 42 respondents and the study involved analysis methods such us Cobb Douglass function by Stochastic Frontier approach, descriptive quantitative by Likert Scale, and Pearson Correlation. The result showed that average level of technical efficiency was about $77 \%$ with $40.5 \%$ neutral farmers risk behaviour and no significant relationship between technical efficiency and farmers risk behavior.
\end{abstract}

Keywords: risk behavior, shallot production, technical efficiency

\begin{abstract}
ABSTRAK
Desa Pojanan Barat Kabupaten Pamekasan dikenal sebagai sentra produksi bawang merah, Varietas Manjung. Bawang merah ini dikenal sebagai produk yang memiliki sifat-sifat unggul seperti: memiliki produktivitas yang tinggi, mampu bertahan pada kondisi lahan yang kering, memiliki ketahanan terhadap hama dan penyakit, serta memiliki aroma yang harum dan sangat gurih. Permasalahan di desa tersebut adalah produktivitasnya tidak sesuai dengan potensi maksimal yang seharusnya bisa dihasilkan. Tujuan penelitian ialah menganalisis tingkat efisiensi teknis, mengetahui perilaku petani dalam menghadapi risiko, dan menganalisis keterkaitan efisiensi teknis dan perilaku risiko petani. Jumlah sampel sebanyak 42 petani. Metode analisis yang digunakan adalah fungsi produksi Cobb Douglas dengan pendekatan Stochastic Frontier, diskriptif kuantitatif dengan menggunakan skala Likert, dan uji korelasi Pearson. Hasil yang diperoleh menunjukkan bahwa petani hanya mampu mencapai tingkat efisiensi teknis rata-rata sebesar $77 \%$, sementara itu $40.5 \%$ petani berperilaku netral terhadap risiko, dan tidak terdapat hubungan yang signifikan antara efisiensi teknis dan perilaku risiko petani.
\end{abstract}

Kata kunci: efisiensi teknis, perilaku risiko, produksi bawang merah

\section{PENDAHULUAN}

Subsektor pertanian yang turut berperan penting dalam perekonomian Indonesia ialah subsektor komoditas hortikultura. Kontribusi subsektor ini dalam Produk Domestik Bruto (PDB) cenderung mengalami peningkatan pada semua komoditas. Hal ini sesuai dengan data
Direktorat Jenderal Hortikultura yang menyebutkan bahwa PDB atas dasar harga berlaku tahun 2010 yang disumbangkan oleh komoditas hortikultura sebesar 73.04 triliun rupiah. Selanjutnya telah terjadi peningkatan kontribusi subsektor komoditas hortikultura sebesar 73.78 triliun rupiah pada tahun 2012 (Ningrum et al., 2013). Komoditas bawang 
merah memiliki potensi besar untuk dikembangkan sebagai komoditas unggulan daerah. Hal ini disebabkan bawang merah termasuk dalam kelompok rempah yang digunakan sebagai bumbu masak dan bahan obat tradisional, sehingga hampir dibutuhkan oleh seluruh kalangan masyarakat. Bawang merah yang tidak memiliki sifat substitusi (dapat digantikan) membuat bawang merah memiliki prospek tinggi untuk dikembangkan, terbukti dari meningkatnya konsumsi bawang merah per kapita per tahun. Pada tahun 2013 konsumsi bawang merah sebesar 20.649 ons kemudian pada tahun 2014 meningkat menjadi 24.872 ons (Kementerian Pertanian, 2015).

Sebagai salah satu daerah penghasil bawang merah, Kabupaten Pamekasan memiliki varietas bawang merah unggulan yang telah dilepas pada tahun 2007 oleh Kementerian Pertanian. Varietas tersebut yaitu bawang merah Manjung. Varietas ini memiliki beberapa keunggulan, diantaranya produktivitas tinggi, dapat bertahan terhadap kondisi lahan yang mengalami kekeringan, memiliki ketahanan yang baik terhadap serangan hama dan penyakit, serta memiliki cita rasa yang gurih dan harum (BPP Kabupaten Pamekasan, 2011)

Kecamatan Batumarmar menjadi sentra produksi bawang merah Manjung di Kabupaten Pamekasan dengan luas panen dan produksi terbesar. Namun luasnya areal panen dan besarnya produksi tidak diimbangi dengan tingginya produktivitas bawang merah di kecamatan tersebut. Menurut Rahmadona et al. (2017) produktivitas usahatani bawang merah di beberapa wilayah di Indonesia tergolong rendah. Hal ini juga terjadi di Desa Ponjanan Barat Kecamatan Batumarmar. Pada tahun 2013, petani bawang merah varietas Manjung di Kecamatan Proppo Kabupaten Pamekasan dapat menghasilkan bawang merah dengan tingkat produktivitas sebesar 7.5 ton $\mathrm{ha}^{-1}$, sedangkan di Kecamatan Batumarmar tingkat produktivitas bawang merah hanya sebesar 6 802 ton ha ${ }^{-1}$ (Dinas Pertanian, 2016), dan salah satunya terjadi di Desa Ponjanan Barat. Rendahnya produktivitas dapat disebabkan karena tingkat efisiensi teknis yang rendah dan adanya risiko produksi. Basuki (2014) menyatakan bahwa usahatani bawang merah memiliki risiko yang cukup tinggi yang bersumber dari serangan penyakit, hama, adanya kabut, dan turunnya hujan. Menurut
Soedjana (2007) terjadinya risiko dalam bidang pertanian disebabkan oleh beberapa faktor, diantaranya: (1) risiko produksi yang disebabkan oleh kejadian-kejadian yang sukar untuk diramalkan misalnya iklim, hama, serangan penyakit, dan mutasi genetik, (2) risiko harga yang dihubungkan dengan bervariasinya serta tidak pastinya harga yang diterima dan yang harus dibayarkan oleh petani dalam pembelian input produksi. Variasi harga yang dimaksud berhubungan dengan tingkat harga, yang kemudian mampu berpengaruh terhadap harapan petani, program pemerintah, serta permintaan konsumen, (3) risiko usaha dan finansial yang berhubungan dengan segala pembiayaan atas usahatani yang dilakukan dimana tingginya risiko usaha diakibatkan oleh tingginya modal baik investasi maupun pinjaman, (4) risiko teknologi yang berhubungan dengan kemampuan petani dalam mengadopsi teknologi sebagai akibat dari kemajuan teknologi yang pesat. Adopsi tersebut akan berpengaruh terhadap pengambilan keputusan petani (misalnya pembelian alat baru) yang nantinya akan berdampak pada tingkat efisiensi usaha-taninya, (5) risiko kerusakan yang berdampak terhadap kehilangan harta. Risiko ini biasanya disebabkan oleh beberapa faktor seperti banjir, kebakaran, angin, pencurian, ataupun inflasi, (6) risiko sosial dan hukum yang berhubungan dengan peraturan ataupun keputusan yang dikeluarkan oleh pemerintah, dan (7) risiko yang bersumber dari manusia yang berhubungan dengan tingkah laku, daya tahan tubuh, dan sifat-sifat yang sulit untuk diprediksi. Selain itu rendahnya produktivitas juga dapat disebabkan oleh perilaku risiko petani atau kesediaan petani untuk mengambil risiko (Ellis, 1989).

Perilaku petani dalam menghadapi risiko dikelompokkan menjadi tiga, yaitu petani risk lover, yang menyukai risiko, petani risk neutral, mereka yang bersikap netral pada risiko dan petani risk averter yaitu petani-petani yang enggan terhadap risiko (Darmawi, 2005). Selanjutnya Saptana et al. (2010) memaparkan bahwa pada dasarnya, kesediaan petani dalam mengambil keputusan untuk memilih ataupun bertindak atas risiko tergantung pada sifat bawaan, dan utility yang diperoleh petani berdasarkan produksi yang dihasilkan (output). Hal ini kemudian akan berdampak pada strategi yang akan digunakan petani. Atas dasar sifat pembawaan psikis masing-masing petani yang 
berbeda, juga akan menyebabkan perbedaan perilaku risiko petani. Perbedaan tersebut akan berdampak pada keputusan masing-masing petani dalam mengalokasikan input yang akan digunakan. Alokasi input yang dipakai selanjutnya akan mempengaruhi produktivitas dan capaian efisiensi petani.

Risiko-risiko yang dihadapi petani pada dasarnya berkaitan dengan kemampuan manajemen petani (Kurniati, 2015). Kemampuan ini dapat membantu petani pada pengambilan keputusan untuk usahataninya. Keputusan tersebut biasanya berhubungan dengan jumlah input yang akan digunakan, sehingga dapat mencegah terjadinya risiko yang mungkin terjadi selama proses budidaya. Keputusan yang diambil petani juga akan berpengaruh pada pengambilan keputusan untuk berusahatani berikutnya. Berkaitan dengan kondisi yang ada, maka penelitian ini memiliki tujuan melakukan analisis tingkat efisiensi teknis, mengetahui perilaku risiko petani, serta menganalisis keterkaitan efisiensi teknis dan perilaku risiko petani.

\section{BAHAN DAN METODE}

Penelitian dilakukan di Desa Ponjanan Barat, Kecamatan Batumarmar, Kabupaten Pamekasan. Pertimbangan yang digunakan pada pemilihan lokasi ialah bahwa Desa Ponjanan Barat memiliki persentase lahan bawang merah tertinggi di Kecamatan Batumarmar. Sampel dalam penelitian ditentukan dengan rumus Slovin, dengan jumlah populasi 870 maka jumlah sampel dalam penelitian ini sebanyak 42 petani.

Menurut Iraizoz et al. (2003) efisiensi teknis dalam sebuah unit produksi menunjukkan pencapaian kemungkinan produksi maksimum berdasarkan pemberian sejumlah faktor-faktor produksi. Dalam penelitian ini, tingkat efisiensi teknis dihitung dengan menggunakan fungsi produksi Cobb Douglas yang di dekati dengan metode Stochastic Frontier dengan program Frontier 4.1. Model produksi dirumuskan dalam bentuk logaritma berikut:

$\mathrm{Ln} \mathrm{YBM}=\ln \beta_{0}+\beta_{1} \ln \mathrm{LL}+\beta_{2} \ln \mathrm{BBT}+\beta_{3} \ln$ $\mathrm{TKJ}+\beta_{4} \ln \mathrm{PNPK}+\beta_{5} \ln \mathrm{PSC}+\beta_{6} \ln \mathrm{PSP}+\beta_{7}$ $\ln \mathrm{PPK}+\mathrm{v}_{\mathrm{i}}-\mathrm{u}_{\mathrm{i}}$
Dimana:

YBM $=$ Produksi bawang merah dalam 1 musim, satuan yang digunakan kilogram

LL = luas lahan diukur dengan satuan hektar

BBT = bibit yang digunakan $(\mathrm{kg})$

$\mathrm{TKJ}=$ penggunaan tenaga $\operatorname{kerja}(\mathrm{HOK})$

$\mathrm{PNPK}=$ pupuk $\mathrm{N}, \mathrm{P}$, dan $\mathrm{K}$ diukur dengan satuan Kilogram

PSC = Pestisida cair yang digunakan (liter)

PSP = Pestisida padat yang terpakai (kilogram)

PPK = Pupuk kandang yang diaplikasikan diukur dalam satuan kilogram

$\beta_{0} \quad=$ intersep

$\beta_{\mathrm{i}}=$ koefisien peubah penduga $(i=1$ sampai 7 ), $0<\beta_{\mathrm{i}}<1$ (diminishing return)

$\mathrm{v}_{\mathrm{i}}-\mathrm{u}_{\mathrm{i}}=$ error term

$\mathrm{v}_{\mathrm{i}} \quad=$ variabel acak yang bebas dan identik terdistribusi normal

$\mathrm{u}_{\mathrm{i}} \quad=$ variabel yang mencerminkan efek inefisiensi dalam usahatani

Perilaku risiko petani dianalisis dengan menggunakan kuisioner yang berisi sejumlah pernyataan yang disusun untuk menilai indikator-indikator dari setiap variabel yang ada (Tabel 1). Masing-masing pernyataan dinilai menggunakan skala Likert dengan 3 kriteria (setuju, netral, dan tidak setuju). Sebelumnya, kuisioner harus telah diuji validitas dan reliabilitas untuk mendapatkan data yang baik.

Kategori perilaku risiko yang digunakan pada penelitian ini yaitu risk lover (menyukai risiko), risk neutral (netral terhadap risiko), dan risk averter (tidak menyukai risiko). Rumus interval digunakan untuk menentukan batas kategori perilaku risiko pada penelitian ini:

interval $=\frac{\text { skor tertinggi-skor terendah }}{\text { jumlah kategori }}$.

Hubungan antara efisiensi teknis dan perilaku risiko diuji dengan menggunakan uji korelasi sederhana. Uji ini dilakukan untuk membuktikan apakah kedua variabel tersebut berhubungan signifikan atau tidak dengan menggunakan taraf kesalahan $(\alpha)$ sebesar 5 persen. Hipotesis atau dugaan sementara yang digunakan adalah 
$\mathrm{H} 0$ = Efisiensi teknis tidak memiliki keterkaitan yang signifikan dengan perilaku risiko.

$\mathrm{H} 1$ = terdapat keterkaitan yang signifikan antara efisiensi teknis dan perilaku risiko.

Dasar pengambilan keputusan berdasarkan hasil analisis tersebut, yaitu:

a. Apabila nilai $\mathrm{r}_{\text {hitung }}<\mathrm{r}_{\text {tabel }}$ atau nilai $\operatorname{sig}>\alpha$, maka menerima $\mathrm{H} 0$ dan menolak H1.

b. Apabila nilai $r_{\text {hitung }} \geq r_{\text {tabel }}$ atau nilai $\operatorname{sig} \leq \alpha$, maka menerima $\mathrm{H} 1$ dan menolak $\mathrm{H} 0$.

\section{HASIL DAN PEMBAHASAN}

\section{Analisis Efisiensi Teknis}

Berdasarkan hasil perhitungan dengan memanfaatkan model fungsi produksi Cobb Douglas, yang didekati dengan teknik Stochastic Frontier pada produksi usahatani bawang merah, Diperoleh nilai efisiensi teknis seperti dalam Tabel 2. Tabel tersebut menunjukkan hasil analisis dengan nilai gamma sebesar 0.9999 pada $\alpha$ sebesar 5\%. Nilai tersebut menunjukkan bahwa sebesar $99.99 \%$ variasi dalam produksi terjadi karena adanya inefisiensi teknis dalam berproduksi. Sedangkan $0.01 \%$ disebabkan oleh efek-efek stokastik lain yang tidak dimasukkan dalam model, misalnya pengaruh iklim dan cuaca, adanya serangan hama maupun penyakit, dan adanya kemungkinan kesalahan dalam pengukuran variabel. Nilai LR sebesar 6.4340 menunjukkan uji penduga dengan menggunakan metode MLE yang dibandingkan dengan tabel retriksi pada tabel Kodde dan Palm. Hasil ini menunjukkan bahwa nilai LR lebih besar dibandingkan nilai kritis $\mathrm{x}^{2}$, yang berarti mampu menjelaskan terjadinya efek inefisiensi pada model. Berdasarkan hasil tersebut dapat dikatakan bahwa petani di lokasi penelitian belum sepenuhnya efisien secara teknis.

Pendugaan peubah pada Tabel 2 menunjukkan bahwa variabel luas lahan dan penggunaan bibit berpengaruh positif secara signifikan pada produksi usahatani bawang merah, sementara itu, variabel pestisida padat, pemberian pupuk kandang, tenaga kerja, penggunaan NPK, dan pestisida cair tidak berpengaruh secara signifikan pada produksi usahatani bawang merah.

Penggunaan lahan untuk budidaya bawang merah memiliki pengaruh yang signifikan dan positif. Hal ini didasarkan pada nilai $\mathrm{t}$ hitung yang signifikan pada derajat kesalahan 5 persen (1.6819). Nilai peubah luas lahan sebesar 0.4322 menunjukkan bahwa jika luas lahan untuk budidaya bawang merah ditingkatkan 1 persen, akan berdampak pada peningkatkan produksi bawang merah sebesar 0.4322 persen, dengan asumsi cateris paribus. Pengaruh luas lahan yang signifikan disebabkan karena lahan pada lokasi yang diteliti masuk dalam kategori jenis lahan yang subur dan sangat cocok untuk digunakan sebagai tempat berusahatani bawang merah.

Tabel 1. Indikator-indikator pengukuran perilaku risiko petani pada usahatani bawang merah varietas Manjung di lokasi penelitian tahun 2016

\begin{tabular}{|c|c|}
\hline No. & Indikator \\
\hline 1. & $\begin{array}{l}\text { Petani bawang merah tidak pesimis untuk tetap melakukan budidaya meskipun telah terjadi } \\
\text { kerugian pembiayaan. }\end{array}$ \\
\hline 2. & $\begin{array}{l}\text { Dibandingkan memiliki banyak usahatani dengan risiko keuntungan rendah, petani bawang } \\
\text { merah lebih memilih untuk memiliki satu usahatani dengan keuntungan tinggi. }\end{array}$ \\
\hline 3. & $\begin{array}{l}\text { Meskipun keadaan pasar untuk komoditas bawang merah tidak menentu, petani lebih } \\
\text { memilih untuk tetap melakukan budidaya. }\end{array}$ \\
\hline 4. & $\begin{array}{l}\text { Petani bawang merah lebih memilih untuk meluangkan waktunya sebanyak mungkin untuk } \\
\text { mengawasi usahatani yang sedang dilakukan. }\end{array}$ \\
\hline 5. & Tren perdagangan dalam usahatani dapat dinikmati oleh petani bawang merah. \\
\hline 6. & $\begin{array}{l}\text { Terjadinya fluktuasi harga dalam berusahatani tidak terlalu diperhatikan oleh petani bawang } \\
\text { merah. }\end{array}$ \\
\hline 7. & $\begin{array}{l}\text { Dibandingkan memperoleh pendapatan dengan keuntungan yang tetap, petani bawang merah } \\
\text { lebih menyukai pertumbuhan modal. }\end{array}$ \\
\hline 8. & $\begin{array}{l}\text { Dibandingkan membiarkan tanaman tumbuh sendiri, petani bawang merah lebih memilih } \\
\text { untuk sesering mungkin melakukan pengawasan terhadap pertumbuhan bawang merah. }\end{array}$ \\
\hline
\end{tabular}


Tabel 2. Pendugaan peubah fungsi produksi usahatani bawang merah varietas Manjung dengan model Cobb Douglas Stochastic Frontier pada lokasi penelitian tahun 2016

\begin{tabular}{lccc}
\hline \multicolumn{1}{c}{ Variabel Input } & \multicolumn{3}{c}{ Metode MLE } \\
\cline { 2 - 4 } & Koefisien & Standar Error & t Hitung \\
\hline Intersep $\left(\beta_{0}\right)$ & 4.4030 & 1.9057 & 2.3104 \\
Luas lahan $\left(\beta_{1}\right)$ & 0.4322 & 0.1527 & $2.8307^{*}$ \\
Bibit $\left(\beta_{2}\right)$ & 0.6443 & 0.3239 & $1.9894^{*}$ \\
Tenaga Kerja $\left(\beta_{3}\right)$ & -0.2577 & 0.1689 & -1.5257 \\
Pupuk NPK $\left(\beta_{4}\right)$ & -0.0420 & 0.0602 & -0.6984 \\
Pestisida Cair $\left(\beta_{5}\right)$ & -0.0620 & 0.1264 & -0.4906 \\
Pestisida Padat $\left(\beta_{6}\right)$ & 0.1004 & 0.2282 & 0.4401 \\
Pupuk Kandang $\left(\beta_{7}\right)$ & 0.2376 & 0.2822 & 0.8422 \\
\hline Sigma-squared & 0.1053 & 0.0146 & 7.1898 \\
\hline$\gamma$ & & 0.9999 & \\
\hline LR & & 6.4340 \\
\end{tabular}

Penambahan luas lahan di daerah penelitian dapat melalui berbagai metode diantaranya dengan memanfaatkan pekarangan yang masih belum termanfaatkan, mengganti komoditas lain yang diusahakan, atau memanfaatkan lahan tidur yang banyak terdapat di sekitar Desa Ponjanan Barat. Penggunaan lahan untuk budidaya bawang merah memiliki pengaruh yang signifikan dan positif. Hal ini didasarkan pada nilai t hitung yang signifikan pada derajat kesalahan 5 persen (1.6819). Nilai peubah luas lahan sebesar 0.4322 menunjukkan bahwa jika luas lahan untuk budidaya bawang merah ditingkatkan 1 persen, akan berdampak pada peningkatkan produksi bawang merah sebesar 0.4322 persen, dengan asumsi cateris paribus. Pengaruh luas lahan yang signifikan disebabkan karena lahan pada lokasi yang diteliti masuk dalam kategori jenis lahan yang subur dan sangat cocok untuk digunakan sebagai tempat berusahatani bawang merah. Penambahan luas lahan di daerah penelitian dapat melalui berbagai metode diantaranya dengan memanfaatkan pekarangan yang masih belum termanfaatkan, mengganti komoditas lain yang diusahakan, atau memanfaatkan lahan tidur yang banyak terdapat di sekitar Desa Ponjanan Barat.

Samadi dan Bambang (2005) mengungkapkan bahwa budidaya bawang merah cocok untuk jenis lahan sawah, tegalan, dan pekarangan. Selain itu, tanaman bawang merah juga cocok untuk ditanam di lahan dengan jenis tanah lempung berpasir dan lempung berdebu. Jenis lahan di Desa Ponjanan Barat yang ditanami bawang merah ialah lahan tegalan dengan jenis tanah lempung berpasir.
Hal ini sejalan dengan penelitian Lawalata $e t a l$. (2015) pada usahatani bawang merah di Kabupaten Bantul yang menjelaskan bahwa perluasan lahan sebesar 1 persen akan meningkatkan hasil usahatani sebesar 0.4038 persen, namun peningkatan luas lahan ini harus sejalan dengan peningkatan penggunaan input, dan manajeman yang tepat.

Bibit yang digunakan oleh responden berpengaruh signifikan dan positif terhadap produksi bawang merah berdasarkan nilai $t$ hitung yang melebihi nilai t tabel (1.9894 > 1.6819) dengan derajat kesalahan $(\alpha)$ sebesar 5 persen. Nilai koefisien bibit sebesar 0.6443 menjelaskan bahwa setiap peningkatan penggunaan bibit sebesar 1 persen, maka berdampak pada peningkatan produksi bawang merah sebesar 0.6443 persen, dengan menggunakan asumsi cateris paribus. Hal ini disebabkan bibit yang digunakan oleh petani responden ialah varietas Manjung yang merupakan varietas unggulan Kabupaten Pamekasan. Selain merupakan varietas unggul, bawang merah Manjung juga memiliki produktivitas tinggi. Penelitian ini sejalan dengan hasil penelitian Basuki (2009), yaitu bahwa petani sangat menyukai karakteristik bawang merah yang secara agronomis mudah diusahakan (unggul) dan memiliki kualitas hasil yang disukai pasar. Sehingga varietas bibit unggul selalu menjadi pertimbangan bagi petani dalam mengadopsinya. Kondisi ini juga sama dengan studi yang dilakukan Laksmi et al., (2012) pada budidaya tanaman padi sawah di Subak Guama. 


\section{Tingkat Efisiensi Teknis}

Pencapaian tingkat efisiensi teknis pada usahatani Bawang merah Varietas Manjung menggunakan indikator yang dikemukakan oleh (Kumbhakar dan Lovell, 2000) yaitu petani dikatakan efisien jika nilai efisiensi teknisnya $\geq 0.8$. Tingkat efisiensi teknis pada lokasi penelitian ditunjukkan pada Tabel 3 . Hasil analisis yang ditunjukkan pada Tabel 3 menjelaskan bahwa tingkat efisiensi teknis yang dicapai oleh petani di lokasi penelitian rata-rata sebesar 0.77 . Hal ini menunjukkan bahwa petani di lokasi penelitian belum efisien dalam berusatahi bawang merah. Petani bawang merah di Desa Ponjanan masih mempunyai kesempatan untuk dapat menghasilkan produksi potensial bawang merah yang lebih besar. Petani memiliki peluang untuk meningkatkan produksi bawang merah sampai sebesar $22.22 \% \quad((1-$ [0.77/0.99])x100\%). Efisiensi teknis akan dicapai apabila petani mampu meningkatkan efisiensi teknis rata-rata hingga mendekati 0.8 .

Rendahnya efisiensi teknis yang dialami petani di lokasi penelitian menunjukkan bahwa petani responden dalam mengalokasikan inputinput yang digunakan masih belum proporsional. Hasil penelitian ini mendukung penelitian Banani et al. (2013) pada usahatani bawang merah di Kabupaten Brebes. Tingkat efisiensi teknis rata-rata di Kabupaten Tana Tidung sebesar $80 \%$. Hal ini menunjukkan petani responden cudah cukup efisien secara teknis, namun masih memiliki kesempatan untuk menambah atau meningkatkan produksinya sebesar 20\%. Efisiensi teknis masih dapat diperbaiki melalui sistem manajemen teknik terbaik yaitu dengan cara mengalokasikan faktor-faktor produksi secara proporsional.

\section{Analisis Perilaku Risiko}

Perilaku risiko pada penelitian ini dibedakan menjadi tiga kategori dengan penentuan kategori berdasarkan hasil skoring dari kuisioner yang dibagikan (Tabel 4). Berdasarkan Tabel 4, sebagian besar petani responden berperilaku netral terhadap risiko. Indikator dalam hal ini adalah jumlah petani yang berperilaku netral menghadapi risiko sebanyak $40.5 \%$ atau 17 orang, sedangkan yang berperilaku takut menghadapi risiko (risk averter) sebanyak $33.3 \%$ atau 14 orang, dan sisanya sebanyak $26.2 \%$ atau 11 orang berperilaku menyukai risiko (risk lover). Skor minimum yang diperoleh petani ialah 12, sedangkan skor maksimum sebesar 21. Tabel tersebut juga menunjukkan bahwa nilai ratarata perilaku risiko petani sebesar 16.67 dengan standar deviasi sebesar 2.396. Hal ini tidak sejalan dengan penelitian Alimi dan Ayanwale (2005) pada usahatani bawang merah di Kabupaten Kebbi, Nigeria. Hasil analisis menunjukkan sebagian besar petani merupakan penghindar risiko (risk averter). Sumbersumber risiko yang paling berpengaruh terhadap usahatani bawang merah diantaranya harga panen, harga bahan baku, kemarau, serangan hama dan penyakit, dan modal.

Tabel 3. Tingkat efisiensi teknis usahatani bawang merah varietas Manjung pada tempat penelitian

\begin{tabular}{ccc}
\hline Indeks Efisiensi & \multicolumn{2}{c}{ Petani Responden pada Usahatani Bawang merah } \\
\cline { 2 - 3 } & Jumlah & Persentase $(\%)$ \\
$0.40-0.49$ & 1 & 2.38 \\
$0.50-0.59$ & 3 & 7.14 \\
$0.60-0.69$ & 11 & 26.19 \\
$0.70-0.79$ & 10 & 23.81 \\
$0.80-0.89$ & 7 & 16.67 \\
$0.90-0.99$ & 10 & 23.81 \\
\hline Total & 42 & 100.00 \\
\hline Efisiensi Teknis Terendah & & \\
Efisiensi Teknis Tertinggi & & 0.48 \\
Rata-Rata Efisiensi Teknis & & 0.99 \\
\hline
\end{tabular}


Tabel 4. Kategori perilaku risiko petani bawang merah di daerah penelitian tahun 2016

\begin{tabular}{llcc}
\hline Skor & Kategori & $\begin{array}{c}\text { Jumlah Responden } \\
\text { (orang) }\end{array}$ & $\begin{array}{c}\text { Persentase } \\
(\%)\end{array}$ \\
\hline $12-15.1$ & Risk Averter & 14 & 33.3 \\
$15.2-18.2$ & Risk Neutral & 17 & 40.5 \\
$18.3-21.3$ & Risk Lover & 11 & 26.2 \\
\hline Total & & 42 & 100 \\
\hline Rata-Rata & & & 16.67 \\
Standar Deviasi & & & 2.396 \\
\hline
\end{tabular}

Petani yang bersikap risk neutral berarti cenderung berani mengambil risiko, akan tetapi mereka juga belum berani untuk mengambil risiko yang besar. Hal ini karena usahatani bawang merah yang dilakukan oleh petani merupakan usaha turun-temurun, sehingga menganggap usahatani bawang merah mampu memberikan keuntungan. Petani risk neutral juga turut memperhitungkan kendala-kendala yang akan dihadapi selama proses budidaya sehingga dapat mengambil keputusan yang benar dalam usahataninya. Hal tersebut sejalan dengan penelitian Kurniati (2015) pada usahatani kedelai, dimana dari 31 petani responden, terdapat 15 orang petani risk neutral. Petani yang bersikap netral terhadap risiko, merupakan kelompok petani yang bersikap rasional dalam memandang risiko, yaitu bahwa pada setiap usaha yang dilakukan ada kemungkinan untuk mendapatkan laba atau menghadapi kerugian.

\section{Keterkaitan Tingkat Efisiensi Teknis dan Perilaku Risiko Petani}

Analisis yang digunakan untuk mengetahui keterkaitan perilaku risiko dan efisiensi teknis di lokasi penelitian ialah Pearson correlation. Hasil yang didapatkan kemudian diperbandingkan dengan nilai $r$ tabel pada derajat kesalahan 5 persen. Taraf signifikansi $(\alpha)$ yang digunakan pada penelitian ini ialah 5\%. Hasil analisis yang diperoleh ditunjukkan pada Tabel 5.

Hasil analisis pearson correlation pada Tabel 5 menjelaskan hubungan perilaku risiko dan efisiensi teknis petani responden di lokasi penelitian sebesar 0.130. Hal ini menjadi indikator bahwa efisiensi teknis dan perilaku risiko memiliki keterkaitan yang sangat rendah. Akan tetapi, keterkaitan antar keduanya bernilai positif yang berarti semakin tinggi perilaku risiko petani maka semakin tinggi pula tingkat efisiensi teknisnya.

Tabel 5 juga menggambarkan tidak ada keterkaitan yang signifikan antara perilaku risiko dan efisiensi teknis di lokasi penelitian. Hubungan tersebut diperoleh dari nilai signifikan yang lebih besar dari $\alpha(0.410>$ $0.05)$. Penyebab rendahnya hubungan perilaku risiko dan efisiensi teknis diduga disebabkan oleh sikap petani dalam mengalokasikan input. Dalam mengalokasikan input, petani cenderung menggunakan input lebih sedikit. Salah satu faktor yang menyebabkan perilaku tersebut ialah keterbatasan modal yang dimiliki petani dibandingkan dengan harga-harga input yang semakin tinggi. Selain itu, input yang dialokasikan petani rata-rata hampir sama meskipun terdapat perbedaan perilaku risiko. Hal inilah yang menjelaskan bahwa perilaku risiko petani responden di lokasi penelitian tidak berpengaruh signifikan terhadap efisiensi teknis usahataninya, seperti ditunjukkan pada Tabel 6 .

Tabel 5. Korelasi tingkat efisiensi teknis dan perilaku risiko petani pada usahatani bawang merah di daerah penelitian tahun 2016

\begin{tabular}{llcr}
\hline & & Tingkat Perilaku & Tingkat Efisiensi \\
& & Risiko & Teknis \\
\hline Tingkat Perilaku Risiko & Pearson Correlation & 1 & 0.130 \\
& Sig. (2-tailed) & 42 & 0.410 \\
& N & 0.130 & 42 \\
Tingkat Efisiensi Teknis & Pearson Correlation & 0.410 & 1 \\
& Sig. (2-tailed) & 42 & 42 \\
\hline
\end{tabular}


Tabel 6. Tingkat efisiensi teknis berdasarkan karakteristik perilaku risiko petani responden pada usahatani bawang merah tahun 2016

\begin{tabular}{cc}
\hline Karakteristik Perilaku Risiko & Tingkat Efisiensi Teknis \\
\hline Risk Averter & 0.75 \\
Risk Neutral & 0.78 \\
Risk Lover & 0.78 \\
\hline
\end{tabular}

Tabel 6 menjelaskan bahwa efisiensi teknis yang dimiliki petani yang takut terhadap risiko tidak berbeda dengan tingkat efisiensi teknis yang dimiliki oleh petani yang bersikap metral terhadap risiko maupun petani yang menyukai risiko. Hal ini karena dalam mengalokasikan input usahataninya, petani responden dibatasi oleh kemampuan petani dalam memperoleh input. Oleh karena itu meskipun petani tersebut berperilaku risk neutral maupun risk lover namun memiliki keterbatasan modal, sehingga tingkat efisiensi teknisnya akan rendah. Begitu pula dengan petani risk averter yang memiliki modal cukup, efisiensi teknis yang diperoleh akan tinggi.

\section{KESIMPULAN}

Hasil analisis yang dilakukan pada usahatani bawang merah di lokasi penelitian mengenai keterkaitan efisiensi teknis dan perilaku risiko petani diperoleh beberapa kesimpulan, yaitu petani bawang merah di daerah penelitian rata-rata masih belum efisien yang ditunjukkan oleh tingkat efisiensi teknis sebesar 0.77. Faktor-faktor produksi yang secara signifikan berpengaruh positif dalam usahatani ini adalah bibit serta luasan lahan yang dipergunakan petani bawang merah sebesar $40.5 \%$ berperilaku netral terhadap risiko. Tidak terdapat hubungan signifikan antara perilaku risiko dan efisiensi pada usahatani bawang merah di lokasi penelitian.

Perbaikan efisiensi teknis bisa dilakukan melalui menambah alokasi input bibit dan luas lahan. Petani dapat melakukan penambahan jumlah bibit pada usahataninya hingga 1.2 ton $\mathrm{ha}^{-1}$. Selain itu, memperbanyak penggunaan jumlah bibit juga dapat dilakukan dengan cara mengurangi jarak tanam hingga menjadi $15 \mathrm{~cm}$ x $15 \mathrm{~cm}$. Penambahan input luas lahan dapat dilakukan dengan memanfaatkan lahan-lahan tidur serta menggunakan semua lahan yang dimiliki petani untuk budidaya bawang merah. Pemanfaatan lahan tidur dapat dilakukan pada beberapa lahan kosong seperti yang terdapat pada lahan kosong di pinggir-pinggir jalan atau lahan milik masyarakat yang memang tidak digunakan untuk budidaya bawang merah.

Petani yang belum efisien dapat meningkatkan efisiensi teknisnya dengan mencontoh sistem budidaya usahatani yang telah dilaksanakan oleh petani yang mampu mencapai tingkat efisiensi teknis tertinggi. Petani tersebut menggunakan input-input untuk per hektar luas lahan yang diusahakan sebanyak $900 \mathrm{~kg}$ bibit, $151.71 \mathrm{HOK}$ tenaga kerja, 99.55 $\mathrm{kg}$ pupuk NPK, $8 \mathrm{~L}$ pestisida cair, $15 \mathrm{~kg}$ pestisida padat, dan $7100 \mathrm{~kg}$ pupuk kandang.

\section{DAFTAR PUSTAKA}

Alimi, T., A. B. Ayanwale. 2005. Risk and risk management strategies in onion production in Kebbi State of Nigeria. Journal of Social Sciences. 10(1): 1-8.

Banani, A., M. Mustadjab, D. Koestiono, Syafrial. 2013. Production management and technical efficiency of red onion farming in Brebes Regency. J. Basic. Appl. Sci. Res. 3(3): 85-90.

Balai Penyuluhan Pertanian, Kabupaten Pamekasan. 2011. Profil Komoditi Unggulan Kabupaten Pamekasan.

Basuki, R.S. 2009. Analisis Tingkat Preferensi Petani terhadap Karakterisitik Hasil dan Kualitas Bawang Merah Varietas Lokal dan Impor. J. Hort. 19(2):237-248

Basuki, R.S. 2014. Identifikasi Permasalahan dan Analisis Usahatani Bawang merah di Dataran Tinggi Pada Musim Hujan di Kabupaten Majalengka. J. Hort. 24 (3): 266-275.

Darmawi, H. 2005. Manajemen Risiko. Bumi Aksara: Jakarta. 
Dinas Pertanian. 2016. Luas Panen, Produksi, dan Produkstivitas Bawang merah di Beberapa Kecamatan di Kabupaten Pamekasan Tahun 2013.

Ellis, F. 1989. Peasant Economic: Farm Household and Agrarian Development Diterjemahkan oleh Adi Sutanto, et. al. UMM Press: Malang.

Iraizoz, B., M. Rapun, I. Zabaleta. 2003. Assessing the technical efficiency of horticultural production in Navarra, Spain. J. Agric. Systems. 78(3): 387403.

Kementerian Pertanian. 2015. Perkembangan Konsumsi Rumah Tangga per Kapita di Indonesia. http://dbprasarana.pertanian. go.id/konsumsi/tampil_susenas2.php. [2 Desember 2015].

Kumbhakar, S.C., C.A.K. Lovell. 2000. Stochastic Frontier Analysis. Cambrige University Press.

Kurniati, D. 2015. Perilaku petani terhadap risiko usahatani kedelai di Kecamatan Jawai Selatan Kabupaten Sambas. J. Social Economic of Agriculture. 4(1): 32-36.

Laksmi, N.M.A.C., I.K. Suamba, I.G.A.A. Ambarawati. 2012. Analisis efisiensi usahatani padi sawah. E-Jurnal Agribisnis dan Agrowisata. 1(1): 34-44.

Lawalata, M., D.H. Darwanto, S. Hartono. 2015. Efisiensi relatif usahatani bawang merah dengan pendekatan Data Envelopment Analysis (DEA). J. Ilmu Pertanian. 18(1): 1-8.

Ningrum, M.H., R. Gultom, M. Manurung. 2013. Analisis PDB Sektor Pertanian Tahun 2013. Pusat Data dan Sistem Informasi Pertanian. Sekretariat Jenderal - Kementerian Pertanian. Jakarta.

Rahmadona, L., Anna F., Burhanuddin. 2017. Dayasaing Komoditas Bawang Merah di Kabupaten Majalengka, Jawa Barat. J. Hort. Indonesia. 8(2): 128-135.

Samadi, B., B. Cahyono. 2005. Bawang merah, Intensifikasi dan Budidaya. Kanisius: Yogyakarta.

Saptana, A. Daryanto, H.K. Daryanto, Kuntjoro. 2010. Analisis efisiensi teknis produksi usahatani cabai merah besar dan perilaku petani dalam menghadapi risiko. Jurnal Agro Ekonomi. 28(2): 153188.

Soedjana, T.D. 2007. Sistem usaha tani terintegrasi tanaman-ternak sebagai respons petani terhadap faktor risiko. J. Litbang Pertanian. 26(2): 82-87. 